\title{
Challenge accepted: uncovering the role of rare genetic variants in Alzheimer's disease
}

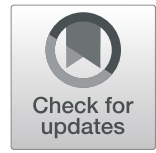

Marzieh Khani', Elizabeth Gibbons ${ }^{2}$, Jose Bras 2,3 and Rita Guerreiro $2,3^{*}$ (i)

\begin{abstract}
The search for rare variants in Alzheimer's disease (AD) is usually deemed a high-risk - high-reward situation. The challenges associated with this endeavor are real. Still, the application of genome-wide technologies to large numbers of cases and controls or to small, well-characterized families has started to be fruitful.

Rare variants associated with AD have been shown to increase risk or cause disease, but also to protect against the development of AD. All of these can potentially be targeted for the development of new drugs.

Multiple independent studies have now shown associations of rare variants in NOTCH3, TREM2, SORL1, ABCA7, BIN1, CLU, NCK2, AKAP9, UNC5C, PLCG2, and ABI3 with AD and suggested that they may influence disease via multiple mechanisms. These genes have reported functions in the immune system, lipid metabolism, synaptic plasticity, and apoptosis. However, the main pathway emerging from the collective of genes harboring rare variants associated with $A D$ is the $A \beta$ pathway. Associations of rare variants in dozens of other genes have also been proposed, but have not yet been replicated in independent studies. Replication of this type of findings is one of the challenges associated with studying rare variants in complex diseases, such as AD. In this review, we discuss some of these primary challenges as well as possible solutions.

Integrative approaches, the availability of large datasets and databases, and the development of new analytical methodologies will continue to produce new genes harboring rare variability impacting AD. In the future, more extensive and more diverse genetic studies, as well as studies of deeply characterized families, will enhance our understanding of disease pathogenesis and put us on the correct path for the development of successful drugs.
\end{abstract}

Keywords: Alzheimer's disease, Genetic architecture, Early-onset AD, Late-onset AD, Rare variants, Genetics

\section{Background}

The main goals of human genetics include the improvement of diagnosis and prognosis of human disease, as well as the identification of therapeutic targets. To accomplish this, it is crucial to fully understand the genetic architecture of diseases, more specifically, to have complete knowledge of all genetic contributions to a given disease outcome and the characteristics of those contributions [1].

\footnotetext{
* Correspondence: Rita.Guerreiro@vai.org

${ }^{2}$ Department of Neurodegenerative Science, Van Andel Institute, 333 Bostwick Ave. N.E., Grand Rapids, Michigan 49503-2518, USA

${ }^{3}$ Division of Psychiatry and Behavioral Medicine, Michigan State University College of Human Medicine, Grand Rapids, MI, USA

Full list of author information is available at the end of the article
}

Alzheimer's disease (AD; Online Mendelian Inheritance in Man [OMIM]\#104300) has a complex nature with contributions from multiple environmental and genetic factors. Clinically is characterized by deficits in short-term memory formation and additional cognitive functions such as word-finding, spatial cognition, reasoning, judgment, and problem-solving [2, 3]. Neuropathologically, it is associated with hallmarks such as the presence of extracellular depositions of amyloid-beta (A $\beta$ ) peptides and intracellular neurofibrillary tangles. The former are a byproduct of sequential cleavage of the amyloid precursor protein (APP) by the enzymatic complexes beta $(\beta)$ and gamma $(\gamma)$ secretase, and the latter are composed of hyperphosphorylated tau protein $[4,5]$. 
Genetically, AD is also complex. According to the age at onset of clinical symptoms, it can be divided into two categories: early-onset $\mathrm{AD}$ (EOAD), if symptoms occur before 65 years, and late-onset AD (LOAD), if symptoms occur after that age. Both forms of the disease can be subdivided into familial and sporadic, according to the presence or absence of a family history of the disease, respectively. Both early and late-onset forms of $\mathrm{AD}$ are considered to have a high degree of heritability, ranging from $90-100 \%$ in EOAD to $60-80 \%$ in LOAD [6, 7]. Most sporadic cases present with late-onset symptoms, and familial inheritance of $\mathrm{AD}$ is typically associated with early-onset forms of the disease. Some AD cases are monogenic, where mutations in one gene cause the disease; the vast majority are sporadic with a polygenic basis. Both common and rare variants contribute to risk and phenotype. Even if considered distinct forms of AD, EOAD and LOAD overlap significantly in clinical, pathological, and genetic features. This means that understanding the genetic architecture of both forms of the disease will be essential to identify potential therapeutic targets, an elusive but critical task given the current absence of effective disease-modifying drugs.

Over the years, considerable advances have been made in characterizing the genes and genetic variants involved in this disease. These advances have been tightly related to developments in genetic technologies, such as the development of platforms for genome-wide association studies and sequencing of exomes and genomes. Still, the genetic factors identified so far account only for a portion of the underlying genetic basis of disease. Thus, we are far from having a complete understanding of the genetic architecture of AD.

With improvements of the technologies and their application to ever-growing numbers of samples, we expect other genes with a role in disease to be identified. Notably, we have most recently seen an increase in the number of rare variants associated with $\mathrm{AD}$, despite the significant challenges related to studying this type of variant. In this review, we will focus on the contributions of rare variants to $\mathrm{AD}$ in the context of its overall genetic architecture.

\section{The genetic architecture of Alzheimer's disease}

The genetic architecture of a disease can be defined as the set of variants influencing a phenotype, the magnitude of their respective effects on the phenotype, their population frequency, and their interactions with each other and the environment [1]. The complete knowledge of the genetic architecture of disease functions as a blueprint that can be used for translational efforts and drug development. The more detailed the blueprint, the more targets will be available for drug development and the better we will understand how they interact, leading to disease. The development of aducanumab is a prime example of this for AD. This is an amyloid beta-directed monoclonal antibody, recently approved by the US Food and Drug Administration, that was generally based on the initial genetic findings of APP, PSEN1, and PSEN2 mutations as causes of $\mathrm{AD}$ and the subsequent development of the amyloid cascade hypothesis [8].

\section{Types of variants and approaches to study them}

Variants in the human genome can range from single nucleotide variants (SNVs) to large structural changes, including copy number variants, translocations, and inversions [9]. All of these can be common (when presenting a minor allele frequency, MAF $\geq 5 \%$ ), have a low frequency (MAF $\geq 1 \%$ and $<5 \%$ ), be rare (MAF $\geq 0.1 \%$ and $<1 \%$ ), or be ultra-rare (MAF $<0.1 \%$, many with the plurality observed only once) in the population. In order to understand the genetic architecture of disease, all the different types of genetic changes need to be assessed and understood in a biological context. Different genetic mapping techniques have been developed that allow the determination of associations between sequence variants and phenotypic variability. Some of these techniques are ideal for testing common variants, while others are more appropriate to assess rare variability. In the past decade, these methodologies have started to interrogate the genome leading to a much more comprehensive view of genetic variability associated with disease.

The first of these methodologies to be applied to the study of AD were genome-wide association studies (GWAS). These platforms use genome-wide genotyping arrays to measure genetic variation and test the association of $\mathrm{AD}$ with common genetic variants by typically comparing frequencies of variants between cases and controls. Different designs of genotyping arrays and the use of imputation strategies have, more recently, allowed for the assessment of lower frequency and rare variants in GWAS.

Direct sequencing is the primary technology for the detection of rare genetic variation. Next-generation sequencing (NGS) technologies in the form of exome and genome sequencing (ES and GS) and several additional cost-effective approaches including targeted sequencing of selected loci, directed genotyping, and improved imputation of large cohorts have been developed for this purpose $[10,11]$. The use of exome-wide microarrays with variants selected from exome sequencing is an alternate approach for the detection of rare variants. The main limitation of genotyping approaches is that they can only test what is known [10]. Sequencing technologies allow for the discovery of novel variants. Variants of small statistical effects can show substantial biological changes of disease relevance. It is important to note that even NGS technologies currently in heavy use have 
limitations, but approaches are being put into place to help. Repeat expansions (e.g. C9orf72) are not detectable in PCR-positive library preps (which have long been standard), but are readily detectable (even in short-read Illumina data) in PCR-free library preparations. Longread sequencing is also being more commonly applied to allow better detection of copy number variants.

\section{Common variability contributing to $A D$}

Common SNVs in APOE (apolipoprotein E) are the most well-known and significant genetic risk modulators for AD. Three main isoforms are encoded by different alleles and vary at positions 112 and 158 of the protein, either carrying a cysteine or an arginine (Transcript ID: ENST00000252486.9, Protein sequence ID: NP 000032.1). These are referred to as $A P O E \varepsilon 2, \varepsilon 3$ and $\varepsilon 4$, with $A P O E \varepsilon 3$ being the most common among human populations, and $\varepsilon 4$ and $\varepsilon 2$ increasing and decreasing the risk for $\mathrm{AD}$, respectively, in a dose-dependent manner $[12,13]$. Non-Hispanic white individuals harboring one or two copies of $A P O E \varepsilon 4$ have an average increased risk of developing $\mathrm{AD}$ of 3 - and 15 -fold, respectively. APOE $\varepsilon 4$ has also been shown to modify the age at onset in both EOAD and LOAD, and it has been reported to have different effects in different populations [14, 15].

It was only with the application of GWAS to AD that additional, replicated genetic loci were identified to be associated with disease risk. The first GWAS in AD, most probably due to the small sample size, only identified $A P O E$ as a risk locus. This confirmed that genetic variation at this locus is the most significant common genetic risk factor for LOAD, and that genetic variation at other loci, individually, confer only minor effects on disease risk [16]. Large-scale GWAS involving over 15,000 samples started to identify other regions of interest in the genome, some of which consistently replicated across studies [17, 18]. Currently, with increased statistical power gained by the use of very large numbers of samples, over 70 risk loci with genome-wide significance have been associated with $\operatorname{AD}[19,20]$. Many of these associations were identified in non-coding regions and were found to be enriched at regulatory sites, with only $2 \%$ of variants associated with LOAD being located within exons [21]. In many cases, the true cause of the association is yet to be defined but the aggregation of loci according to their biological effects has led to a better understanding of the biological pathways involved in AD etiology. These include some obvious pathways, such as the $A \beta$ and tau pathways, immune system and neuroinflammation pathways, and several others like lipid and glucose metabolism, synaptic plasticity, neurogenesis, axon outgrowth, blood-brain barrier integrity. These pathways are not independent of each other and often work in a synergic way in the central nervous system [10].

Results from GWAS have also been used to determine polygenic risk scores (PRS). These scores allow the individualized risk prediction in which an individual's risk for $\mathrm{AD}$ is determined by the combinatorial effect of multiple variants acting together across the genome [22]. PRS will be essential for the identification and stratification of at-risk individuals who may benefit from early therapeutic interventions. To this end, an approach has been proposed that, in addition to the typical PRS using common variants, also accounts for the varying disease prevalence in different genotype and age groups when modeling the $A P O E$ and rare genetic variants risk [23]. This is an important approach since rare variants, and in particular, singletons can have a substantial contribution to the heritability of complex diseases [24].

\section{Rare variants in Alzheimer's disease}

Heritability estimates for AD suggest that approximately only $33 \%$ of the genetic variance of sporadic $\mathrm{AD}$ is accounted for by common variants, indicating that the genetic architecture of $\mathrm{AD}$ is more complex than that proposed by the "common disease, common variant" hypothesis that GWAS are designed to test [25]. This puts ultra-rare, rare, and low-frequency variation (referred here as 'rare variants' for simplicity) in the spotlight as potential contributors to AD's 'missing heritability' [24, $26,27]$. As per definition, this type of genetic variability will not contribute to disease in many individuals, making it difficult to understand their importance in disease and why we should study them. In fact, rare variants usually have larger effect sizes on disease risk, especially when compared to the common variants identified by GWAS, because they typically have a more deleterious impact on protein function. Additionally, as mentioned above, the methods used to identify rare variants associated with disease typically point to a specific gene (and not to a genomic region), making it easier to predict the effects of the variants by using cell or animal models.

Consequently, studying these rare variants often leads to a significantly improved understanding of disease mechanisms and can better pinpoint specific therapeutic targets. This has been the case for the development of the "amyloid cascade hypothesis". It suggests that amyloid deposition is the initial causative event in a cascade of symptoms resulting in neurodegeneration and cognitive decline [8], which was based on the initial discovery of APP mutations as the cause of familial early-onset $\mathrm{AD}$, leading to a central dogma that has guided research in $\mathrm{AD}$ for many years. Similarly, the more recent finding of TREM2 rare variants as risk factors for $\mathrm{AD}$ has put immune cell function and inflammatory pathways at the center stage of AD research [28]. 


\section{Genes harboring rare variants that cause $A D$}

Linkage studies in multi-generational EOAD families with autosomal dominant inheritance identified mutations in three genes as the cause of the disease: amyloid precursor protein $(A P P)$, presenilin 1 (PSEN1), and presenilin 2 (PSEN2) $[29,30]$. In APP, more than 50 highly penetrant mutations have been identified, mainly localized near the secretases' cleavage sites and in the domain encoding for the Abeta peptide. Also, APP triplications (both as small events or in trisomy 21) can cause AD as well. In general, these mutations cause an increase in the production of amyloid or the propensity of amyloid aggregation. Similarly, mutations in PSEN1 and PSEN2 also result in an increased production of more aggregation-prone and longer species of Abeta. This occurs because both proteins are part of the $\gamma$-secretase complex responsible for APP processing [31]. Mutations in PSEN1 contribute to around $80 \%$ of the monogenic forms of $\mathrm{AD}$, while mutations in PSEN2 are much less common. The clinical effects of mutations in PSEN2 are more variable than those observed for PSEN1 and APP. For example, ages at onset for PSEN2 mutation carriers range from 40 to 85 years of age [32], and some PSEN2 mutations seem to exhibit reduced penetrance [33, 34].

Interestingly, sequencing studies have also identified rare variants in these three genes that increase the risk for LOAD [35].

\section{Replicated genes harboring rare variants with reduced penetrance and contributing to $A D$ risk}

In the first study applying $\mathrm{ES}$ to $\mathrm{AD}$, we identified a previously known mutation (p.Arg1231Cys) in the notch receptor 3 gene $(\mathrm{NOTCH} 3)$ in a Turkish patient from a consanguineous family, clinically diagnosed with AD. Mutations in this gene, and this specific variant, had been previously shown to cause cerebral autosomal dominant arteriopathy with subcortical infarcts and leukoencephalopathy (CADASIL). Segregation analysis led to identifying the same variant in one unaffected at-risk individual, raising the possibility of incomplete penetrance of the variant in the family. The consanguinity and the spectrum of different phenotypes observed in the family, which included other neurodegenerative and immune diseases, complicated the definite association of this specific variant with $\mathrm{AD}$. Additionally, the resequencing of NOTCH3 in 95 EOAD patients and 95 controls did not reveal any additional rare $\mathrm{NOTCH} 3$ variants that could be associated with disease [36], and this finding remained inconclusive. In a subsequent study investigating the role of genes known to be causative of adult-onset leukodystrophies in $\mathrm{AD}$, we again identified variants in $\mathrm{NOTCH} 3$ to be associated with $\mathrm{AD}$. We sequenced ten genes in 332 non-Hispanic white
$\mathrm{AD}$ patients and 676 controls of old age. The genebased analysis was significant for $\mathrm{NOTCH} 3$, with the signal being driven by one common synonymous variant (p.Pro1521Pro) and three rare coding variants with large effect sizes (p.Val1952Met, p.Val1183Met, p.His170Arg) [37]. The carrier frequency of the three rare coding variants was 2-3 times higher in LOAD patients when compared to control individuals, and all three variants had previously been significantly associated with severity of white matter lesions in elderly individuals with hypertension [37, 38]. More recently, in a larger study of $\mathrm{AD}$ performed by the Alzheimer Disease Sequencing Project (ADSP), more than $5000 \mathrm{AD}$ patients and 4500 controls were tested using ES to identify rare variants associated with the disease. The NOTCH3 p.Ala284Thr was found in 10 $\mathrm{AD}$ patients and no controls, further confirming the link between this gene and AD [39].

In 2013, after identifying triggering receptor expressed on myeloid cells 2 (TREM2) homozygous mutations as the cause of atypical frontotemporal dementia in three Turkish families [40] we expanded the genetic analyses of this gene to include other dementias. When assessing a cohort of non-Hispanic white AD patients $(n=1092)$ and controls $(n=1107)$, we identified a significantly increased frequency of rare heterozygous variants in cases. The p.Arg47His variant, specifically, showed a strong and significant association with the risk of disease, confirmed by direct genotyping in an extended cohort of $1887 \mathrm{AD}$ patients and 4061 control individuals and a meta-analysis of 3 independent GWAS [41]. A similar finding was made after sequencing the genomes of 2261 Icelanders, conclusively implicating TREM2 in the pathogenesis of $\mathrm{AD}$ [42]. After these studies, associations have been reported across different populations [28], and in a large LOAD family ( $n=21$ affected individuals), p.Arg47His was found to co-segregate entirely with the disease [43]. In 2017, it was shown that a second TREM2 rare coding variant (p.Arg62His) increased the risk for sporadic AD independently of p.Arg47His [11].

Rare variants with a role in AD have also been identified in genes located within loci where common variants had previously been associated with AD risk by GWAS. These include variants in the TP-binding cassette, subfamily A, member 7 ( $A B C A 7)$, in the sortilin-related receptor 1 (SORL1), in the Bridging integrator 1 (BIN1), and in the Clusterin $(C L U)$ genes. In $A B C A 7$ and SORL1, an enrichment in rare variants has been reported in $A D$ patients compared to controls, and rare variants have been identified in families with different degrees of cosegregation with the disease. In both genes, the rare variants associated with disease, which include missense and premature termination codon (PTC) variants, are also found in controls, suggesting variable penetrance. 
In $A B C A 7$, this enrichment is mainly associated with protein-truncating variants across the transcript and suggests haploinsufficiency as the most likely disease mechanism. Families presenting with an autosomal dominant mode of $\mathrm{AD}$ inheritance have been found to carry rare $A B C A 7$ variants segregating with the disease [44]. De Roeck and colleagues observed incomplete nonsensemediated decay (NMD) of ABCA7 transcripts harboring PTC variants [45]. For some variants, the induced PTC could be removed from the transcript by using cryptic splice sites. However, alternative splicing only explained variable expression levels in a minimal number of patients.

ES in 14 unrelated EOAD probands of French families identified five carriers of PTCs in SORL1 [46]. This study was, however, unable to test family members due to the unavailability of DNA samples. Still, subsequent studies have confirmed a role for rare variants in this gene in AD [47, 48], particularly for PTCs, again suggesting a haploinsufficiency mechanism [49]. Missense and splice site rare variants in this gene have also been suggested to play a role in autosomal dominant $\mathrm{AD}, \mathrm{LOAD}$, and EOAD families with parkinsonian features [50-52]. Additionally, bi-allelic loss-of-function of SORL1 was observed in one AD patient with parental history of dementia [53].

In BIN1, the rare variant p.Lys358Arg was found to segregate in 2 of 6 Caribbean Hispanic families where the variant was identified. Still, no significant association was found with LOAD in non-Hispanic whites in the same study [54]. The p.Pro318Leu variant was also found to be significantly associated with LOAD in the Han Chinese population [55].

$C L U$ was one of the first loci to be identified as associated with $\mathrm{AD}$ in GWAS. In addition to common variants in the gene, more recently, rare variants have also been shown to have a role in this disease [56]. This type of variability in $C L U$ has, so far, not been described as segregating in $\mathrm{AD}$ families. The potential role of rare heterozygous variants in the gene in $\mathrm{AD}$ was based on the unbiased resequencing of all $C L U$ coding exons and regulatory regions in $\mathrm{AD}$ patients and control individuals from Flanders-Belgium. This study identified rare variants (p.Thr345Met, p.Asn369His, p.Thr440Met, p.Arg338Trp, and p.Thr445_Asp447del) clustering in the CLU $\beta$-chain domain [56].

Genome-wide meta-analysis using rare variant imputation identified a novel association of a rare variant (rs143080277) in NCK adaptor protein 2 (NCK2) with $\mathrm{AD}$ [57]. The same variant was identified in a genomewide meta-analysis, fine-mapping, and integrative prioritization study. It is however difficult to assess how independent the cohorts used in these two studies are, and consequently if this finding is truly independently replicated [58].
The application of ES to study seven African American AD patients with a positive family history identified two rare variants in A-kinase anchor protein 9 (AKAP9). These variants (rs149979685 and rs144662445) were also associated with $\mathrm{AD}$ risk when comparing cases and controls [59]. Another rare variant in AKAP9 (p.Arg434Trp) was identified in two large families segregating with the disease [60].

The p.Thr835Met rare coding variant in the Unc-5 homolog $\mathrm{C}$ (UNC5C), was found to segregate with disease in two families presenting with LOAD and was associated with disease risk in four independent cohorts [61]. Additional rare variants in the gene have been identified in European families (p.Ala860Thr, identified in two families, and p.Pro666Ser) and Chinese cases (p.Gln860His, p.Thr837Lys, p.Ser843Gly, and p.Val836Val) $[62,63]$.

In 2017, a GWAS using an exome microarray identified genome-wide significant associations between rare variants in TREM2, phospholipase C gamma 2 (PLCG2), and ABI Family Member $3(A B I 3)$ and AD risk [11]. The PLCG2 variant p.Pro522Arg was a protective variant (discussed more below), while the $A B I 3$ p.Ser209Phe variant increased the risk for the development of $\mathrm{AD}$ [11]. Significant associations of both the PLCG2 and $A B I 3$ variants with $\mathrm{AD}$ were also observed in other populations $[64,65]$.

Details as MAF and ancestry for the variants identified in these studies are shown in Supplementary Table 1.

\section{Genes harboring rare variants with an initial association to $A D$}

Several new candidate genes have been recently reported to harbor rare variants associated with $\mathrm{AD}$ risk or are potential causes of the disease but currently lack consistent support from other studies. Typically small studies have identified these using familial settings or, more recently, by using ES or GS in families and case-control cohorts. For example, by exome sequencing a Jewish Israeli consanguineous family originating from Morocco and clinically diagnosed with early-onset AD, we identified a homozygous CTSF mutation (p.Gly415Arg) as the most probable cause of disease in the family [66]. The identification of this variant was based on a previous analysis of extended regions of homozygosity shared by the siblings, but no definite segregation could be established due to the number of samples available for the study [67]. Since these findings, no additional report implicated genetic changes in CTSF in AD, which remains an inconclusive association. More recently, and as an example of the use of next-generation sequencing in larger cohorts, Prokopenko and colleagues assessed rare variants by performing single-variant and spatial clusteringbased testing in a family-based GS-based association 
study. This included 2247 subjects from 605 multiplex AD families, followed by replication in 1669 unrelated individuals. They identified 13 novel AD candidate loci that yielded consistent rare-variant signals in discovery and replication cohorts: FNBP1L, SEL1L, LINC00298, PRKCH, C15ORF41, C2CD3, KIF2A, APC, LHX9, NALCN, CTNNA2, SYTL3, and CLSTN2 [68]. These novel candidate genes will need to be replicated by independent studies to fully establish the association with $\mathrm{AD}$.

An exome-wide age-of-onset analysis revealed a synonymous rare variant (rs56201815) in endoplasmic reticulum to nucleus signaling 1 (ERN1) to be associated with a higher risk of $\mathrm{AD}$, particularly in $A P O E \& 4$ noncarriers [69].

Other candidate genes are represented in Table 1. From these, it is interesting to note that an exome sequencing study of non-Hispanic white families identified rs137854495 in ATP binding cassette subfamily A member $1(A B C A 1)$ as segregating with disease in one family [70]. This variant was identified under a family-specific linkage peak on chromosome 9 , adding evidence to its role in disease.

Processing of amyloid-beta emerges as the main biological pathway associated with $\mathrm{AD}$ when analyzing gene sets harboring rare variants. This is true for genes confirmed to harbor rare variants associated with $\mathrm{AD}$ and for genes that have rare variants with an initial association with $\mathrm{AD}$, that need to be independently replicated (Fig. 1). This is interesting to note as APP metabolism has mainly been associated with $\mathrm{AD}$ using pathway analyses when common variants were assessed by GWAS in very large sample sizes, and confirms the nominal association for the amyloid-beta pathway obtained by Kunkle et al. when using rare variants [21, 90].

It will be very challenging to replicate these candidate variants and genes in truly independent cohorts, given the sample size needed to detect and associate most of these rare variants. Resources like the UK Biobank will be valuable in these efforts and functional follow up of the findings will be important to understand the true roles of these variants in disease.

\section{Rare protective variants}

Rare protective variants are of high interest as they can be used as a model for the development of drugs mimicking their effects.

In 2014 Medway and colleagues investigated rare variants within the $A P O E$ locus and identified the rare haplotype $A P O E \varepsilon 3 b$ harboring the p.Val236Glu variant on the $\varepsilon 3$ background and significantly associated with a decrease in $\mathrm{AD}$ risk comparable to that of the $A P O E \varepsilon 2$ allele [91]. More recently, an individual from a large Colombian $\mathrm{AD}$ kindred carrying the pathogenic PSEN1
p.Glu280Ala mutation was described to be remarkably resistant to the clinical onset of autosomal dominant $\mathrm{AD}$ dementia. ES confirmed the presence of the PSEN1 p.Glu280Ala mutation and revealed two copies of the rare $A P O E \varepsilon 3$ p.Arg136Ser variant. The potential protective effect of the $A P O E \varepsilon 3$ p.Arg136Ser variant on disease onset, suggests this variant can be a model for the development of novel therapies [92].

In the same Icelandic population where TREM2 p.Arg47His was identified as a risk factor for AD, Jonsson and colleagues also identified a rare variant in $A P P$ (rs63750847, p.Ala637Thr) with a MAF of $0.01 \%$, that was significantly more common in elderly healthy individuals than in $\mathrm{AD}$ subjects, indicative of a protective effect against the development of AD. Additionally, the protective allele was found to be associated with increased performance on cognitive tests in elderly cognitively normal participants, suggesting the protective effect of the variant is not limited to $\mathrm{AD}$ pathogenesis but also affects cognition in individuals within the healthy spectrum of aging [93].

The previously mentioned protective variant (rs72824905, p.Pro522Arg) identified in PLCG2, the gene encoding the enzyme phospholipase-C- $\gamma 2$ that is highly expressed in microglia, was found to be associated with 1.5-fold reduced risk of $\mathrm{AD}$ in a three-stage case-control study of 83,133 subjects of European ancestry. The variant is located in a regulatory domain, conferring a small hypermorphic effect on enzyme activity [94] and has been shown to enhance microglial functions in a Plcy2P522R knock-in mouse model [95]. PLCY2 regulates microglial functions via TREM2-dependent and -independent signaling pathways being potentially involved in the transition to a microglial state associated with neurodegenerative disease [96]. This variant was also shown to reduce $\mathrm{AD}$ disease progression by mitigating tau pathology in the presence of amyloid pathology. The protective effect was more pronounced in MCI patients with low A $\beta 1-42$ levels, suggesting a role of PLCG2 in the response to amyloid pathology [97]. Adding to the notion that p.Pro522Arg exerts its strongest effect downstream of amyloid pathology, Sierksma and colleagues also found PLCG2 as part of a unique gene expression module specifically responsive to $A \beta$ but not TAU pathology [98]. Altogether, these findings support the idea that a weak lifelong activation of the PLCG2 pathway may confer protection against $\mathrm{AD}$, and pharmacological modulation of microglia via TREM2-PLCY2 pathway-dependent stimulation may be a novel therapeutic option for the treatment of AD.

Even though no individual rare variants in the MS4A gene cluster and $A B C A 1$ have reached consistent statistical significance in association with the risk of $\mathrm{AD}$, a 
Table 1 Genes/loci harboring rare variants in AD that need independent replication

\begin{tabular}{|c|c|c|c|c|c|}
\hline $\begin{array}{l}\text { Gene } \\
\text { symbol }\end{array}$ & Gene & Location & Variant & Ref & Pathway \\
\hline$A A R D$ & $\begin{array}{l}\text { Alanine and arginine rich domain } \\
\text { containing protein }\end{array}$ & $8 q 24.11$ & Gene burden & {$[71]$} & N.A. \\
\hline$A B C A 1$ & $\begin{array}{l}\text { ATP binding cassette subfamily A } \\
\text { member } 1\end{array}$ & $9 q 31.1$ & $\begin{array}{l}\text { rs137854495, NM_005502.4:C.2810C>T: } \\
\text { p.Ala937Val }\end{array}$ & {$[70]$} & $\begin{array}{l}\text { A } \beta \text { pathway } \\
\text { Lipoprotein metabolism }\end{array}$ \\
\hline ADAM10 & $\begin{array}{l}\text { ADAM metallopeptidase domain } \\
10\end{array}$ & $15 q 21.3$ & $\begin{array}{l}\text { rs61751103, NM_001110.4:c.510G>C: } \\
\text { p.GIn170His } \\
\text { rs145518263, NM_001110.4:c.541A>G: } \\
\text { p.Arg181Gly }\end{array}$ & {$[72]$} & $\begin{array}{l}\text { A } \beta \text { pathway } \\
\text { Apoptosis, phagocytosis, autophagy }\end{array}$ \\
\hline ADAM17 & $\begin{array}{l}\text { ADAM metallopeptidase domain } \\
17\end{array}$ & $2 p 25.1$ & $\begin{array}{l}\text { rs142946965, NM_003183.6:c.644G>T: } \\
\text { p.Arg215lle }\end{array}$ & [73] & $\begin{array}{l}\text { A } \beta \text { pathway } \\
\text { Immune system } \\
\text { Apoptosis, phagocytosis, autophagy }\end{array}$ \\
\hline ANXA5 & Annexin A5 & $4 q 27$ & Gene burden & {$[71]$} & Immune system \\
\hline$A P C$ & $\begin{array}{l}\text { APC regulator of WNT signaling } \\
\text { pathway }\end{array}$ & $5 q 22.2$ & Spatial clustering & {$[68]$} & $\begin{array}{l}\text { A } \beta \text { pathway } \\
\text { Axonal pathfinding } \\
\text { Synaptic plasticity }\end{array}$ \\
\hline ASRGL 1 & $\begin{array}{l}\text { Asparaginase and isoaspartyl } \\
\text { peptidase } 1\end{array}$ & $11 q 12.3$ & 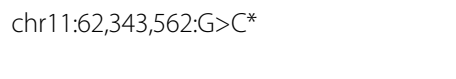 & {$[60]$} & $\begin{array}{l}\text { Axonal guidance and cytoskeleton function } \\
\text { Apoptosis, phagocytosis, autophagy }\end{array}$ \\
\hline BACE2 & Beta-secretase 2 & $\begin{array}{l}21 \mathrm{q} 22.2- \\
\mathrm{q} 22.3\end{array}$ & $12 \mathrm{~Kb}$ intronic deletion & [74] & $\begin{array}{l}\text { A } \beta \text { pathway } \\
\text { Apoptosis, phagocytosis, autophagy }\end{array}$ \\
\hline $\begin{array}{l}\text { Clorf173/ } \\
\text { ERICH3 }\end{array}$ & Glutamate rich 3 & $1 \mathrm{p} 31.1$ & Gene burden & {$[71]$} & N.A. \\
\hline $\begin{array}{l}\text { C15ORF41/ } \\
\text { CDIN1 }\end{array}$ & CDAN1 interacting nuclease 1 & $15 q 14$ & $\begin{array}{l}\text { rs141228575, NM_001130010.3:c.213- } \\
\text { 2446C>T } \\
\text { rs147002962, NM_001130010.3:c.102- } \\
\text { 13586C>G }\end{array}$ & {$[68]$} & Erythrocyte differentiation \\
\hline$C 2 C D 3$ & $\begin{array}{l}\text { C2 domain containing } 3 \text { centriole } \\
\text { elongation regulator }\end{array}$ & $11 q 13.4$ & Spatial clustering & {$[68]$} & $\begin{array}{l}\text { Cilium assembly } \\
\text { Ciliary basal body plasma membrane } \\
\text { docking }\end{array}$ \\
\hline CASP7 & Caspase 7 & $10 q 25.3$ & $\begin{array}{l}\text { rs116437863, NM_001267057.1: } \\
\text { c.1045A>G:p.Arg297Gly }\end{array}$ & [71] & $\begin{array}{l}\text { A } \beta \text { pathway } \\
\text { Immune system } \\
\text { Apoptosis, phagocytosis, autophagy }\end{array}$ \\
\hline$C D 2 A P$ & CD2 associated protein & $6 p 12.3$ & $\begin{array}{l}\text { rs116754410, NM_012120.3: } \\
\text { c.1898A>G:p.Lys633Arg } \\
\text { rs138727736, NM_012120.3: } \\
\text { c.1120A>G:p.Thr374Ala }\end{array}$ & {$[54]$} & $\begin{array}{l}\text { Immune system } \\
\text { Cytoskeleton function } \\
\text { BBB integrity } \\
\text { Apoptosis, phagocytosis, autophagy }\end{array}$ \\
\hline CD55 & $\begin{array}{l}\text { CD55 molecule (Cromer blood } \\
\text { group) }\end{array}$ & $1 \mathrm{q} 32.2$ & $\begin{array}{l}\text { chr1:207461994C>T (upstream of } \\
\text { CD55) }\end{array}$ & [75] & Immune system \\
\hline CLDN17 & Claudin 17 & $21 \mathrm{q} 21.3$ & Homozygosity and gene burden & {$[76]$} & BBB integrity \\
\hline CLSTN2 & Calsyntenin 2 & $3 q 23$ & Spatial clustering & {$[68]$} & $\begin{array}{l}\text { Morphology of synaptic complexes } \\
\text { Calcium-mediated postsynaptic signaling } \\
\text { Episodic memory } \\
\text { Signal transduction }\end{array}$ \\
\hline$C R 1$ & Complement C3b/C4b receptor 1 & $1 \mathrm{q} 32.2$ & $\begin{array}{l}\text { rs11587944, NM_000651.6:C.313C>T: } \\
\text { p.Arg105Cys } \\
\text { rs372477607, NM_000651.6:C.4021C>T: } \\
\text { p.Pro1341Ser }\end{array}$ & {$[60]$} & $\begin{array}{l}\text { A } \beta \text { pathway } \\
\text { Immune system } \\
\text { Apoptosis, phagocytosis, autophagy }\end{array}$ \\
\hline CSF1R & $\begin{array}{l}\text { Colony stimulating factor } 1 \\
\text { receptor }\end{array}$ & $5 q 32$ & $\begin{array}{l}\text { rs281860278, NM_001288705.3: } \\
\text { c.2603T>G:p.Leu868Arg } \\
\text { rs748641028, NM_001288705.3: } \\
\text { c.2073G>C: p.GIn691His } \\
\text { rs111943087, NM_001288705.3: } \\
\text { c.2107C>T:p.His703Tyr }\end{array}$ & {$[37]$} & $\begin{array}{l}\text { Immune system } \\
\text { BBB integrity } \\
\text { Cytoskeleton function }\end{array}$ \\
\hline CTNNA2 & Catenin alpha 2 & $2 p 12$ & Spatial clustering & {$[68]$} & $\begin{array}{l}\text { Neuronal migration and neuritic outgrowth } \\
\text { Cell-cell adhesion }\end{array}$ \\
\hline CTSF & Cathepsin F & $11 \mathrm{q} 13.2$ & $\begin{array}{l}\text { rs200426008, NM_003793.4: } \\
\text { c.1243G>A: p.Gly415Arg }\end{array}$ & {$[66]$} & $\begin{array}{l}\text { Immune system } \\
\text { Apoptosis, phagocytosis, autophagy }\end{array}$ \\
\hline
\end{tabular}


Table 1 Genes/loci harboring rare variants in AD that need independent replication (Continued)

\begin{tabular}{|c|c|c|c|c|c|}
\hline $\begin{array}{l}\text { Gene } \\
\text { symbol }\end{array}$ & Gene & Location & Variant & Ref & Pathway \\
\hline DPP6 & Dipeptidyl peptidase like 6 & $7 q 36.2$ & $\begin{array}{l}\text { Chr7:149,704,610 - 153,786,893 } \\
\text { paracentric inversion* }\end{array}$ & {$[77]$} & Synaptic plasticity \\
\hline EPHA1 & EPH receptor $\mathrm{A} 1$ & $\begin{array}{l}7 \mathrm{q} 34- \\
\mathrm{q} 35\end{array}$ & $\begin{array}{l}\text { rs202178565, NM_005232.5:c.1379C>T: } \\
\text { p.Pro460Leu }\end{array}$ & {$[54]$} & $\begin{array}{l}\text { Immune system } \\
\text { Axonal guidance } \\
\text { Synaptic plasticity } \\
\text { BBB integrity } \\
\text { Apoptosis, phagocytosis, autophagy }\end{array}$ \\
\hline ERN1 & $\begin{array}{l}\text { Endoplasmic reticulum to nucleus } \\
\text { signaling } 1\end{array}$ & $17 q 23.3$ & $\begin{array}{l}\text { rs56201815, NM_001433.5:C.1017C>T: } \\
\text { p.Asp339= }\end{array}$ & {$[69]$} & $\begin{array}{l}\text { Autophagy } \\
\text { Unfolded protein response (UPR) and } \\
\text { neuronal apoptosis }\end{array}$ \\
\hline $\begin{array}{l}\text { EXOC3L4/ } \\
\text { C140rf73 }\end{array}$ & $\begin{array}{l}\text { Exocyst complex component } 3 \\
\text { like } 4\end{array}$ & $14 q 32.32$ & $\begin{array}{l}\text { rs117708804, NM_001077594.1: } \\
\text { c.1126G>T:p.Ala376Ser } \\
\text { rs10142287, NM_001077594.1: } \\
\text { c.687C>A:p.Pro229= } \\
\text { rs9324055, NM_001077594.1: } \\
\text { c.889G>A: p.Val297Met } \\
\text { rs148718670, NM_001077594.1: } \\
\text { c.1937G>A: p.Arg646Gln }\end{array}$ & [78] & N.A. \\
\hline FERMT2 & $\begin{array}{l}\text { FERM domain containing kindlin } \\
2\end{array}$ & $14 q 22.1$ & $\begin{array}{l}\text { rs17125944, NM_001134999.1:c.158- } \\
\text { 14555A>G }\end{array}$ & {$[70]$} & Cell adhesion \\
\hline FNBP1L & Formin binding protein 1 like & $1 \mathrm{p} 22.1$ & $\begin{array}{l}\text { rs192471919, NM_001164473.2:C.1652- } \\
\text { 634T>C }\end{array}$ & {$[68]$} & $\begin{array}{l}\text { Endocytosis } \\
\text { Autophagy } \\
\text { Neurite elongation and axonal branching } \\
\text { (neuroplasticity) }\end{array}$ \\
\hline FSIP2 & $\begin{array}{l}\text { Fibrous sheath interacting protein } \\
2\end{array}$ & $2 q 32.1$ & $\begin{array}{l}\text { rs531170562, NM_173651.4:C.742C>T: } \\
\text { p.Arg248Cys } \\
\text { rs552474258, NM_173651.4:C.743G>T: } \\
\text { p.Arg248Leu }\end{array}$ & {$[70]$} & Spermatogenesis \\
\hline IGHG3 & $\begin{array}{l}\text { Immunoglobulin heavy constant } \\
\text { gamma } 3 \text { (G3m marker) }\end{array}$ & $14 q 32.33$ & $\begin{array}{l}\text { rs77307099, ENST00000390551.2: } \\
\text { c.938G>A, p.Ser313Asn } \\
\text { rs78376194, ENST00000390551.2: } \\
\text { c.939C>T, p.Ser313= } \\
\text { rs12890621, ENST00000390551.2: } \\
\text { c.674A >T, p.Tyr225Phe }\end{array}$ & {$[79]$} & Neuroinflammation \\
\hline KIF2A & Kinesin family member $2 \mathrm{~A}$ & $5 q 12.1$ & Spatial clustering & {$[68]$} & $\begin{array}{l}\text { Mitotic spindle activity and normal brain } \\
\text { development Microtubule-based processes } \\
\text { Ciliogenesis } \\
\text { Cortical development } \\
\text { Spinal cord injuries }\end{array}$ \\
\hline LHX9 & LIM homeobox 9 & $1 \mathrm{q} 31.3$ & Spatial clustering & {$[68]$} & Development of the forebrain \\
\hline $\begin{array}{l}\text { LincRNA } \\
\text { LINC00298 }\end{array}$ & $\begin{array}{l}\text { Long intergenic noncoding RNA } \\
\text { LINC00298 }\end{array}$ & $2 p 25.1$ & rs147918541, chr2:8073233:G>A & {$[68]$} & May be involved in neuronal plasticity \\
\hline $\begin{array}{l}\text { LncRNA } \\
\text { AC099552.4 }\end{array}$ & $\begin{array}{l}\text { Long non-coding RNA } \\
\text { AC099552.4 }\end{array}$ & $7 q 36.3$ & chr7:154988675:G>A & {$[79]$} & Gene expression regulation \\
\hline $\begin{array}{l}\text { LncRNA } \\
\text { RP11-433J8 }\end{array}$ & $\begin{array}{l}\text { Long non-coding RNA RP11- } \\
\text { 433J8 }\end{array}$ & $14 q 32.2$ & chr14:97228875:A>G & {$[70]$} & N.A. \\
\hline MAPT & $\begin{array}{l}\text { Microtubule associated protein } \\
\text { tau }\end{array}$ & $17 q 21.31$ & $\begin{array}{l}\text { NM_001123066.3:C.370C>A: } \\
\text { p.GIn124Ly } \\
\text { NM_001123066.3:c.2203T>G: } \\
\text { p.Ser735Ala }\end{array}$ & {$[80]$} & $\begin{array}{l}\text { Tau pathway } \\
\text { Axonal guidance and cytoskeleton } \\
\text { functioning } \\
\text { Apoptosis, phagocytosis, autophagy }\end{array}$ \\
\hline MARK4 & $\begin{array}{l}\text { Microtubule affinity regulating } \\
\text { kinase } 4\end{array}$ & $19 q 13.32$ & $\begin{array}{l}\text { NM_001199867.1: c.946_ } \\
\text { 951delGGTGAGinsGAT:p.Gly316_ } \\
\text { Glu317delinsAsp }\end{array}$ & {$[74]$} & $\begin{array}{l}\text { Tau pathway } \\
\text { Cytoskeleton function } \\
\text { Apoptosis, phagocytosis, autophagy }\end{array}$ \\
\hline MYRF & Myelin regulatory factor & $11 q 12.2$ & $\begin{array}{l}\text { rs34038946, NM_001127392.3: } \\
\text { c.2167G>A:p.Ala723Thr }\end{array}$ & {$[60]$} & $\begin{array}{l}\text { Lipid metabolism } \\
\text { Synaptic plasticity }\end{array}$ \\
\hline NALCN & $\begin{array}{l}\text { Sodium leak channel, non- } \\
\text { selective }\end{array}$ & $\begin{array}{l}13 q 32.3- \\
q 33.1\end{array}$ & Spatial clustering & {$[68]$} & Neuronal excitability \\
\hline
\end{tabular}


Table 1 Genes/loci harboring rare variants in AD that need independent replication (Continued)

\begin{tabular}{|c|c|c|c|c|c|}
\hline $\begin{array}{l}\text { Gene } \\
\text { symbol }\end{array}$ & Gene & Location & Variant & Ref & Pathway \\
\hline PIN1 & $\begin{array}{l}\text { Peptidylprolyl cis/trans isomerase, } \\
\text { NIMA-interacting } 1\end{array}$ & 19p13.2 & c.477C $>$ T, p.Thr152Met ${ }^{*}$ & [81] & $\begin{array}{l}\text { Aß pathway } \\
\text { Tau pathway } \\
\text { Apoptosis, phagocytosis, autophagy }\end{array}$ \\
\hline PINX1 & $\begin{array}{l}\text { PIN2 (TERF1) interacting } \\
\text { telomerase inhibitor } 1\end{array}$ & $8 p 23.1$ & Gene burden & {$[82]$} & Telomere integrity \\
\hline PRKCH & Protein kinase $C$ eta & $14 q 23.1$ & Spatial clustering & {$[68]$} & Signal transduction \\
\hline PSD2 & $\begin{array}{l}\text { Pleckstrin and Sec7 domain } \\
\text { containing } 2\end{array}$ & $5 q 31.2$ & $\begin{array}{l}\text { rs138380367, NM_032289.4: } \\
\text { c.1549G>A: p.Gly517Ser }\end{array}$ & {$[83]$} & Endolysosomal transport \\
\hline RTN3 & Reticulon 3 & $11 q 13.1$ & $\begin{array}{l}\text { rs372883387, NM_001265589.2:C.- } \\
\text { 8G>T } \\
\text { NM_001265589.2:c.42C>T: p.Ser14= } \\
\text { NM_001265589.2: c.116C>T: } \\
\text { p.Thr39Met } \\
\text { rs11551944: NM_001265589.2: } \\
\text { c.17C>A:p.Ala6Glu }\end{array}$ & {$[84]$} & $\begin{array}{l}\text { A } \beta \text { pathway } \\
\text { Lipid metabolism } \\
\text { Apoptosis, phagocytosis, autophagy }\end{array}$ \\
\hline RUFY1 & $\begin{array}{l}\text { RUN and FYVE domain } \\
\text { containing } 1\end{array}$ & $5 q 35.3$ & $\begin{array}{l}\text { rs138313632,NM_025158.5:c.2113T>G: } \\
\text { p.Ser705Ala }\end{array}$ & {$[83]$} & Endolysosomal transport \\
\hline SEL1L & $\begin{array}{l}\text { SEL1L adaptor subunit of ERAD } \\
\text { E3 ubiquitin ligase }\end{array}$ & $14 q 31.1$ & rs74065194, chr14:82182068: C>T & {$[68]$} & $\begin{array}{l}\text { A } \beta \text { pathway } \\
\text { Endoplasmic reticulum-associated } \\
\text { degradation (ERAD) } \\
\text { ER stress and cell death }\end{array}$ \\
\hline SEZ6 & Seizure related 6 homolog & $17 q 11.2$ & $\begin{array}{l}\text { rs371753097, NM_178860.5: } \\
\text { c.1844G>A:p.Arg615His }\end{array}$ & {$[85]$} & $\begin{array}{l}\text { A } \beta \text { pathway } \\
\text { Synaptic plasticity }\end{array}$ \\
\hline $\begin{array}{l}\text { SLC24A4- } \\
\text { RIN3 }\end{array}$ & $\begin{array}{l}\text { Solute carrier family } 24 \text { member } \\
\text { 4-Ras and Rab interactor } 3\end{array}$ & $14 q 32.12$ & $\begin{array}{l}\text { SLC24A4:rs10498633, NM_153646.4: } \\
\text { c.1255+4000G>T } \\
\text { RIN3:rs147042536, NM_024832.5: } \\
\text { c.2377T>C, : p.Tyr793His } \\
\text { RIN3: rs150221413, NM_024832.5: } \\
\text { c.189G>T, : p.Trp63Cys }\end{array}$ & $\begin{array}{l}{[60,} \\
83]\end{array}$ & $\begin{array}{l}\text { SLC24A4: } \mathrm{Na}+\mathrm{Ca} 2+, \mathrm{K}+\text { exchange } \\
\text { RIN3:Endolysosomal transport }\end{array}$ \\
\hline SRCAP & $\begin{array}{l}\text { Snf2 related CREBBP activator } \\
\text { protein }\end{array}$ & $16 p 11.2$ & 10 ultra-rare missense mutations & {$[86]$} & Gene expression regulation \\
\hline SYTL3 & Synaptotagmin like 3 & $6 q 25.3$ & Spatial clustering & {$[68]$} & Vesicle trafficking \\
\hline TCIRG1 & $\begin{array}{l}\text { T cell immune regulator } 1 \text {, } \\
\text { ATPase } \mathrm{H}+\text { transporting V0 } \\
\text { subunit a3 }\end{array}$ & $11 q 13.2$ & $\begin{array}{l}\text { rs34227834, NM_006019.4:C.482C>T, : } \\
\text { p.Pro161Leu }\end{array}$ & {$[83]$} & $\begin{array}{l}\text { Endolysosomal transport } \\
\text { Immune system }\end{array}$ \\
\hline$\pi C 3$ & $\begin{array}{l}\text { Tetratricopeptide repeat domain } \\
3\end{array}$ & $21 q 22.13$ & $\begin{array}{l}\text { rs377155188, NM_001001894.2: } \\
\text { c.3113C>G: p.Ser1038Cys }\end{array}$ & {$[87]$} & $A \beta$ pathway \\
\hline TYROBP & $\begin{array}{l}\text { Transmembrane immune } \\
\text { signaling adaptor TYROBP }\end{array}$ & $19 q 13.12$ & $\begin{array}{l}\text { rs200649978, NM_003332.4:c.5G>A: } \\
\text { p.Gly2Glu } \\
\text { NM_003332.3:c.163G>T: p.Val55Leu }\end{array}$ & {$[88]$} & $\begin{array}{l}\text { A } \text { pathway } \\
\text { Immune system } \\
\text { Lipid metabolism } \\
\text { Apoptosis, phagocytosis, autophagy }\end{array}$ \\
\hline VPS35 & $\begin{array}{l}\text { VPS35 retromer complex } \\
\text { component }\end{array}$ & $16 q 11.2$ & NM_018206.6:c.1874T>C: p.Leu625Pro & [74] & $\begin{array}{l}\text { A } \beta \text { pathway } \\
\text { Apoptosis, phagocytosis, autophagy }\end{array}$ \\
\hline VWA2 & $\begin{array}{l}\text { Von Willebrand factor A domain } \\
\text { containing } 2\end{array}$ & $10 q 25.3$ & $\begin{array}{l}\text { rs79009215, NM_001272046.2: } \\
\text { c.1096G>A:p.Val366Met }\end{array}$ & {$[89]$} & N.A. \\
\hline ZNF655 & Zinc finger protein 655 & $7 q 22.1$ & Gene burden & [79] & Gene expression regulation \\
\hline
\end{tabular}

Genes and loci reported to harbor rare variants that have been associated with AD, their chromosomal locations and respective biological pathways and processes. Variants shown here represent the original associations established with $A D$ in the respective studies. When the findings were focused on gene or regional burden analyses, that is noted, instead of specific variants. *As reported in the original publication. AD, Alzheimer's disease; A $\beta$, Amyloid-beta; BBB, BloodBrain Barrier; ERAD, Endoplasmic reticulum-associated degradation; ER stress, Endoplasmic reticulum stress; UPR, Unfolded protein response. 

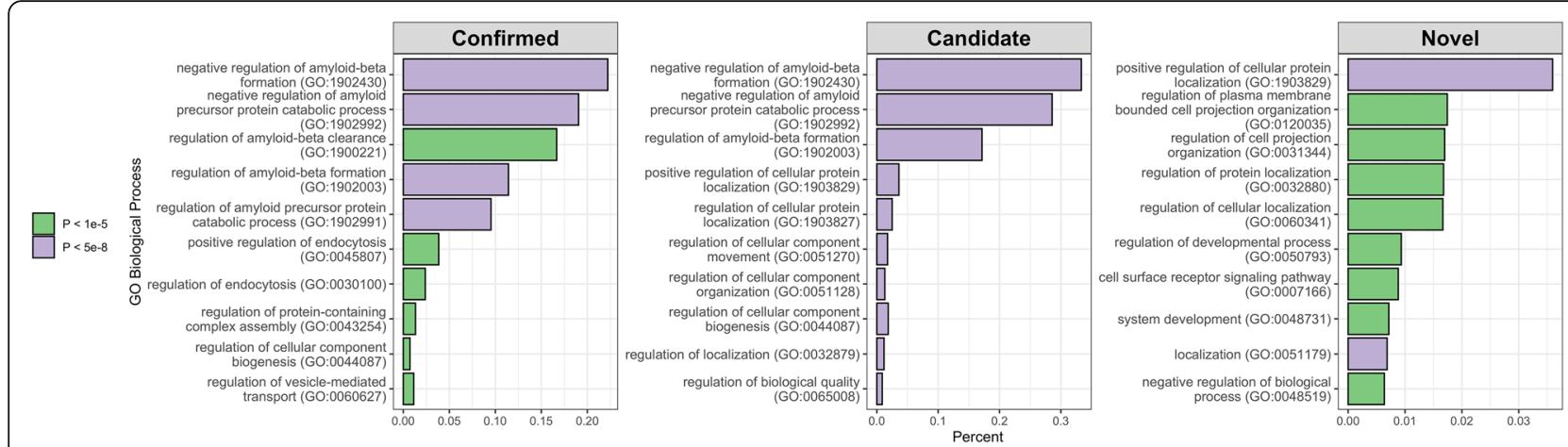

Fig. 1 Top results (based on Fisher's Exact test p-value) for Confirmed (genes with strong evidence or replication) or Candidate (suggestive role, replication needed) in $A D$, based on the genes described in this review. Also shown are pathways emerging only with the addition of these Candidate genes (Novel). Gene set analyses were performed using the Gene Ontology website (http://geneontology.org/), analyzing the provided biological processes of the gene set. The X-axis represents the percent of the pathway represented out of total genes possible for that pathway. Y-axis shows gene ontology terms and IDs. The color of the bars indicates the significance level.

higher, nominally significant burden of rare coding variants has been found in controls compared to AD in both cases. Screening of the MS4A gene cluster in $210 \mathrm{AD}$ cases and 233 controls identified missense and loss-offunction variants twice as frequently in controls than cases [99]. Similarly, a rare variant candidate gene study sequencing 311 LOAD cases and 360 controls found that 1.7 times as many controls had at least one rare variant $(\mathrm{MAF}<0.05)$ in $A B C A 1$ than cases [100]. This suggests that similarly to $A P P$, rare variability in this gene may be associated with both protective and causative roles in $\mathrm{AD}$.

\section{The challenges when studying rare variants}

Identifying rare variants and their subsequent association with disease risk is much more complex and less powerful than for common variants. Several factors contribute to this, mainly related to the methodologies used to detect and analyze variants.

An example of how difficult it is to assess the true association of rare variants with a specific disease comes from the description of Phospholipase D3 gene (PLD3) as a risk gene for AD. Using ES, Cruchaga and colleagues studied 14 LOAD families and identified a rare variant (p.Val232Met) in PLD3 segregating with the disease in two of these families. In the same report, the subsequent analyses in large case-control cohorts also showed a significant association between the variant and $\mathrm{AD}$, as did the burden analysis for the gene. PLD3 was also shown to be involved in amyloid- $\beta$ precursor protein processing and was found to be overexpressed in brain tissue from patients with AD [101]. More recently, a study using human brain tissue and mouse models has suggested that PLD3 has an important role in AD through lysosomal dysfunction. Nackenoff A. et al. established PLD3 as a lysosomal phospholipase D and showed that the $\mathrm{AD}$-associated variant identified by Cruchaga and colleagues impaired its function. PLD3 expression levels were also found to correlate with $\beta$ amyloid plaque density and the rate of cognitive decline in humans. Similarly, PLD3 expression levels correlated with memory and learning in a genetically diverse mouse model [102]. However, since the initial association of PLD3 with AD, independent studies with sufficient power to detect similar genetic effects have all failed to replicate the association [103-107]. This lack of statistical evidence for association in independent cohorts highlights the complexity of establishing rare variants as contributors to complex diseases. In this case, it may be due to different scenarios: it may indicate that the initial association was actually a false positive, it may represent such a small effect that the signal is not consistently identifiable in other cohorts, or it can reflect a genetic influence only in familial settings. In the latter scenario, it would represent an effect in very rare families, as additional mutations in the gene have not been identified so far in other $\mathrm{AD}$ families.

\section{Methodological challenges}

As previously mentioned, rare variants are typically detected and assessed using either microarrays or nextgeneration sequencing technologies. GS is the only methodology that virtually assesses the totality of variability in one sample. Microarrays will only test known variants included in the array's design, and ES will generally not detect non-coding variants. When working with genotyping calls of rare variants, it is often needed to confirm the genotyping clusters visually, and when working with GS data, it is usually necessary to have access to high power computing. This is particularly true when performing analyses of GS data in the large numbers of samples required for meaningful associations of 
rare variants with disease (see next section). Given the cost and computing needs, most sequencing studies aimed at detecting rare variants have used ES. To increase the study's sample size, it has been common to merge data from different sources and/or perform targeted sequencing. While this is relatively straightforward when performing GWAS using data from genotyping arrays, it is more complex when merging data generated using different exome capture methods and with varying coverage [108]. Sequence capture uniformity and capture probe performance will determine how much raw sequence data for each sample will be available and, consequently, impact downstream analyses [109].

\section{Sample sizes}

When studying rare variants in the context of disease, sample sizes are critical for detecting variants and establishing their association with disease risk. Even before establishing an association with disease, it is already challenging to detect rare variants: it is necessary to study at least 460 or 4600 individuals to detect alleles, with a probability of $99 \%$, with frequencies of $0.5 \%$ or $0.05 \%$, respectively [110]. To obtain sufficient statistical power, the association of rare variants with risk of disease requires larger sample sizes than those needed to associate common variants. For example, when the effect size of a variant is 0.1 phenotyping standard deviation units (corresponding to an odds ratio of $\sim 1.2$ ), a common variant with MAF $=10 \%$ needs $\sim 10,000$ individuals to obtain genome-wide significance at $P=5 \times 10-8$ with $80 \%$ statistical power. Variants with MAFs of $1 \%$ and $0.1 \%$ require $\sim 100,000$ and 1 million individuals, respectively [111]. It is commonly accepted that a well-powered rare variant association study should involve discovery sets with at least 25,000 cases, and a substantial replication set [112]. Consequently, the typical GWAS approach of analyzing one variant at a time is typically underpowered for rare variants unless the variant effect is substantial. Methods collapsing several rare variants together have been developed to overcome this, but these still require large sample sizes. This is the case of the latest large gene burden study encompassing a total of 32,558 samples (16,036 AD cases and 16,522 controls) that led to the identification of 11 genes associated with $\mathrm{AD}$-risk, of which rare variants in eight genes were not previously significantly associated with the disease [113].

One way to overcome the challenge of large sample sizes is to study isolated or distinct populations. An ultra-rare variant in one population may be more frequent in another population. A prime example is the APP p.Ala637Thr variant previously mentioned. This variant is virtually absent in Asian and African populations, has a MAF of 0.0003 in European non-Finish populations and of 0.003 in the Finnish. This distribution of frequencies makes it very unlikely that the finding of its protective role in $\mathrm{AD}$ could have been done outside Iceland.

\section{Impact and interpretation of rare variants}

The analyses of ever larger sample sizes and the development of improved statistical methods lead to increased statistical power in the association of rare variants with $\mathrm{AD}$ risk. At the same time, the study of wellcharacterized and carefully selected families can also result in the identification of rare variants with significant roles in the pathogenesis of AD. However, both in casecontrol association studies and in familial settings, an important limiting factor continues to be assessing the impact of the variants and their interpretation in the context of disease.

The development of in silico prediction software and the active cataloging of rare variants in publicly available databases have contributed significantly to interpreting the effects of rare variants in genes and proteins. These are particularly useful, given the sheer number of variants typically detected in an individual exome or genome. For example, CADD is a popular tool used to predict the pathogenicity of clinical variants. It uses a logistic regression model and dozens of genomic features to learn the characteristics of randomly generated variants and distinguish these from recently fixed variants in humans [114]. However, this type of predictors is limited by the data available for most genes, including the number of known pathogenic variants and associated functional data. More recently, machine learning techniques such as deep learning have been used for genome functional annotation and assessment of variant function [115]. With better computer power and the increase in the amount of data available, this type of approach will allow for more and better results. And in cases with limited data, as often occurs for poorly studied genes and ultra-rare variants, alternative approaches such as transfer learning can be applied to study rare variants by using the information on genes similar to the gene of interest, for example [116].

It is crucial to keep in mind that a variant that damages a gene or protein is not necessarily damaging in terms of health and disease [117]. The interpretation of pathogenicity of rare variants and the understanding of their relevance to disease needs the integration of diverse data. Essential factors to consider include the prevalence and mode of inheritance of the disease. Also, genetic heterogeneity, reduced penetrance and variable expressivity of the variant, composite phenotypes, pleiotropy, and epistasis should all be taken into account [118].

Variant interpretation refers to the process of connecting individual variants to disease phenotypes. This is a complex process that may have a significant impact on a 
patient's diagnosis or treatment. The guidelines developed by the American College of Medical Genetics (ACMG) provided a systematic way of understanding the clinical significance of any given sequence variant and have set the standards for this process [119]. Still, this continues to be a challenging process dependent on expert interpretation based on literature review. These guidelines are general, and there is an imminent need to establish procedures and databases specific to different genes and diseases.

\section{The ultimate challenge: rare non-coding variants}

As previously mentioned, the vast majority of variants identified as associated with AD risk by GWAS are located in non-coding regions of the genome. It has been challenging to pinpoint the true functional variant(s) at these loci and, most importantly, understand how these changes influence the molecular mechanisms and risk of disease [120]. To accomplish this, fine-mapping and expression quantitative trait loci (eQTL)-based approaches have been used to identify multiple candidate causal genes, and have demonstrated significant associations between AD risk and gene expression. It is, thus, critical to have detailed information from functional mapping with the identification of regulatory elements, causal cell types/tissue(s), genes, and pathways. These approaches provide insight into likely mechanisms of actions of candidate genes for further functional validation in cell and animal models [121].

When analyzing GS data, it is common to discard this type of variability to streamline the data analysis process. This is done because the probability of being able to discern a true effect of a rare non-coding variant in disease is low, and because of the need to reduce the number of variants to be analyzed in detail. Nonetheless, the Encyclopedia of DNA Elements (ENCODE) project emphasized that as much as $80 \%$ of the non-protein-coding portion of the genome is associated with biochemical 'function' [122], clearly highlighting the importance of assessing non-coding variability in $\mathrm{AD}$ and other diseases. Efforts like the Atlas of Variant Effect Alliance are working toward this end with the major goal of interpreting the impact of all genomic variation. These initiatives are essential as non-coding variant prioritization tools are less accurate than their protein-coding counterparts and there is currently insufficient understanding of the regulatory machinery encrypted in non-coding DNA [117].

Some recent studies have attempted to incorporate non-coding information into burden analyses when studying complex diseases, including $\mathrm{AD}$. Examples are the identification of CAV1 as an ALS risk gene, after performing a burden analysis for rare variants within enhancers [123], and the identification of 5 loci containing rare alleles with a substantial contribution to the heritability of type 2 diabetes, using islet annotation to create a non-coding framework for rare variant aggregation testing [124].

In $\mathrm{AD}$ (and other neurodegenerative diseases) noncoding and loss-of-function coding variants in TET2 were associated with disease [125]. These results need to be independently replicated, particularly given the potential somatic origin of TET2 mutations, and the disparity in age between cases and controls used [126].

\section{Conclusion}

Advances in genetic technology and analysis methods have led to a faster pace in the identification of rare genetic variability as the cause of $\mathrm{AD}$ or associated with an increase or decrease of its risk. As a result, rare variants such as those in TREM2, SORL1, and ABCA7 are now well established. However, many rare variants identified in novel genes are still waiting to be replicated. This is challenging given the sample sizes required and the need for independent replication cohorts.

The ultimate goal of understanding genetic risk mechanisms is to translate genetic association to novel drug targets and therapeutics to prevent or delay the onset of disease. Drug discovery and development for a complex disease like $\mathrm{AD}$ are exceptionally challenging. This challenge is compounded by an incomplete understanding of AD pathogenesis, the multifactorial etiology and complex pathophysiology of the disease, and importantly, by the lack of good in vivo models of AD to translate knowledge from genetics to drugs. Nelson and colleagues showed that genes associated with variation in human traits have provided more targets for successful therapeutic drugs than those without such links. They also suggested that well-studied genes known to be associated with disease proceed better in the drug development pipeline. In addition, they estimate that the success rate in clinical development could be doubled by selecting genetically supported targets [127]. In conclusion, drug development can be facilitated by genetic and genomic knowledge. A complex disease like AD will most likely not be treated by one individual drug. Having multiple targets that allow the development of drugs acting in different steps of the multiple biological pathways involved in $\mathrm{AD}$ will probably be a viable approach. For this to happen in the near future we need to continue detailing the genetic architecture of AD. Potential ways forward will most likely include improved methods of simultaneous assessing common and rare variants; the integration of several layers of information such as expression, methylation, biological pathways, and clinical data; and the inclusion of data from publicly available databases and large datasets such as the UK Biobank, Genomics England and gnomAD. 
The continuous sharing of data and resources will be the only way to fully understand the biological mechanisms, enable drug development and advance the clinical diagnosis and disease management of such a complex disease as AD.

\section{Abbreviations}

AD: Alzheimer's disease; Aß: Amyloid-beta; ADSP: Alzheimer Disease Sequencing Project; ACMG: American College of Medical Genetics; BBB: Blood-Brain Barrier; CADASIL: Cerebral autosomal dominant arteriopathy with subcortical infarcts and leukoencephalopathy; EOAD: Early-onset AD; ERAD: Endoplasmic reticulum-associated degradation; ER stress: Endoplasmic reticulum stress; eQTL: Expression quantitative trait loci;

ENCODE: Encyclopedia of DNA Elements; GWAS: Genome-wide association studies; LOAD: Late-onset AD; MAF: Minor allele; MCl: Mild cognitive impairement; NGS: Next-generation sequencing; NMD: Nonsense-mediated decay; OMIM: Online Mendelian Inheritance in Man; PTC: Premature termination codon; PRS: Polygenic risk scores; SNVs: Single nucleotide variants; UPR: Unfolded protein response; ES: Exome sequencing; GS: Genome sequencing

\section{Supplementary Information}

The online version contains supplementary material available at https://doi. org/10.1186/s13024-021-00505-9.

\section{Additional file 1.}

\section{Acknowledgments}

Not Applicable.

\section{Authors' contributions}

All authors read and approved the final manuscript.

\section{Authors' information}

Not Applicable.

\section{Funding}

The authors' work is supported in part by the National Institute on Aging of the National Institutes of Health (R01AG067426).

\section{Availability of data and materials}

Not Applicable.

\section{Declarations}

\section{Ethics approval and consent to participate}

Not Applicable.

\section{Consent for publication}

Not Applicable.

\section{Competing interests}

The authors declare that they have no competing interests.

\section{Author details}

${ }^{1}$ School of Biology, College of Science, University of Tehran, Tehran, Iran. ${ }^{2}$ Department of Neurodegenerative Science, Van Andel Institute, 333 Bostwick Ave. N.E., Grand Rapids, Michigan 49503-2518, USA. ${ }^{3}$ Division of Psychiatry and Behavioral Medicine, Michigan State University College of Human Medicine, Grand Rapids, MI, USA.

Received: 10 August 2021 Accepted: 6 December 2021

Published online: 09 January 2022

\section{References}

1. Timpson NJ, Greenwood CMT, Soranzo N, Lawson DJ, Richards JB. Genetic architecture: the shape of the genetic contribution to human traits and disease. Nat Rev Genet. 2018;19:110-24.
2. Bettens K, Sleegers K, Van Broeckhoven C. Current status on Alzheimer disease molecular genetics: from past, to present, to future. Hum Mol Genet. 2010;19:R4-11.

3. Cacace $\mathrm{R}$, Sleegers K, Van Broeckhoven C. Molecular genetics of early-onset Alzheimer's disease revisited. Alzheimers Dement. 2016;12:733-48.

4. Hardy J. Amyloid, the presenilins and Alzheimer's disease. Trends Neurosci. 1997;20:154-9.

5. Selkoe DJ. Biochemistry and Molecular Biology of Amyloid $\beta$-Protein and the Mechanism of Alzheimer's Disease. Handbook of Clinical Neurology. Elsevier; 2008. p. 245-260.

6. Wingo TS, Lah JJ, Levey Al, Cutler DJ. Autosomal recessive causes likely in early-onset Alzheimer disease. Arch Neurol. 2012;69:59-64.

7. Gatz M, Pedersen NL, Berg S, Johansson B, Johansson K, Mortimer JA, et al. Heritability for Alzheimer's disease: the study of dementia in Swedish twins. J Gerontol A Biol Sci Med Sci. 1997;52:M117-25.

8. Hardy J, Higgins G. Alzheimer's disease: the amyloid cascade hypothesis [Internet]. Science. 1992. p. 184-5. Available from: https://doi.org/10.1126/ science.1566067

9. Frazer KA, Murray SS, Schork NJ, Topol EJ. Human genetic variation and its contribution to complex traits. Nat Rev Genet. 2009;10:241-51.

10. Sims R, Hill M, Williams J. The multiplex model of the genetics of Alzheimer's disease. Nat Neurosci. 2020;23:311-22.

11. Sims R, van der Lee SJ, Naj AC, Bellenguez C, Badarinarayan N, Jakobsdottir $\mathrm{J}$, et al. Rare coding variants in PLCG2, ABI3, and TREM2 implicate microglial-mediated innate immunity in Alzheimer's disease. Nat Genet. 2017:49:1373-84.

12. Liu C-C, Liu C-C, Kanekiyo T, Xu H, Bu G. Apolipoprotein E and Alzheimer disease: risk, mechanisms and therapy. Nat Rev Neurol. 2013;9:106-18.

13. Corder EH, Saunders AM, Strittmatter WJ, Schmechel DE, Gaskell PC, Small GW, et al. Gene dose of apolipoprotein E type 4 allele and the risk of Alzheimer's disease in late onset families. Science. 1993;261:921-3.

14. Farrer LA, Adrienne Cupples L, Haines JL, Hyman B, Kukull WA, Mayeux R, et al. Effects of Age, Sex, and Ethnicity on the Association Between Apolipoprotein E Genotype and Alzheimer Disease: A Meta-analysis. JAMA. American Medical Association. 1997;278:1349-56.

15. Locke PA, Conneally PM, Tanzi RE, Gusella JF, Haines JL. Apolipoprotein E4 allele and Alzheimer disease: Examination of allelic association and effect on age at onset in both early-and late-onset cases. Genet Epidemiol. Wiley Online Library. 1995;12:83-92.

16. Coon KD, Myers AJ, Craig DW, Webster JA, Pearson JV, Lince DH, et al. A high-density whole-genome association study reveals that APOE is the major susceptibility gene for sporadic late-onset Alzheimer's disease. J Clin Psychiatry. 2007;68:613-8.

17. Harold D, Abraham R, Hollingworth P, Sims R, Gerrish A, Hamshere ML, et al. Genome-wide association study identifies variants at CLU and PICALM associated with Alzheimer's disease. Nat Genet. 2009;41:1088-93.

18. Lambert J-C, Heath S, Even G, Campion D, Sleegers K, Hiltunen M, et al. Genome-wide association study identifies variants at CLU and CR1 associated with Alzheimer's disease. Nat Genet. 2009;41:1094-9.

19. Wightman DP, Jansen IE, Savage JE, Shadrin AA, Bahrami S, Holland D, et al. A genome-wide association study with 1,126,563 individuals identifies new risk loci for Alzheimer's disease. Nat Genet. 2021;53:1276-82.

20. Bellenguez C, Küçükali F, Jansen I, Andrade V, Moreno-Grau S, Amin N, et al. New insights on the genetic etiology of Alzheimer's and related dementia [Internet]. bioRxiv. medRxiv; 2020. Available from: http://medrxiv.org/lookup/ doi/10.1101/2020.10.01.20200659

21. Kunkle BW, Grenier-Boley B, Sims R, Bis JC, Damotte V, Naj AC, et al. Genetic meta-analysis of diagnosed Alzheimer's disease identifies new risk loci and implicates A 3 , tau, immunity and lipid processing. Nat Genet. 2019;51:414-30.

22. Desikan RS, Fan CC, Wang Y, Schork AJ, Cabral HJ, Cupples LA, et al. Genetic assessment of age-associated Alzheimer disease risk: Development and validation of a polygenic hazard score. PLoS Med. 2017;14:e1002258.

23. Escott-Price V, Schmidt KM. Probability of Alzheimer's disease based on common and rare genetic variants. Alzheimers Res Ther. 2021;13:140.

24. Hernandez RD, Uricchio LH, Hartman K, Ye C, Dahl A, Zaitlen N. Ultrarare variants drive substantial cis heritability of human gene expression. Nat Genet. 2019;51:1349-55.

25. Guerreiro RJ, Gustafson DR, Hardy J. The genetic architecture of Alzheimer's disease: beyond APP. PSENs and APOE. Neurobiol Aging. 2012;33:437-56.

26. Saint Pierre A, Génin E. How important are rare variants in common disease? Brief Funct Genomics. 2014;13:353-61. 
27. Schork NJ, Murray SS, Frazer KA, Topol EJ. Common vs. rare allele hypotheses for complex diseases. Curr Opin Genet Dev. 2009;19:212-9.

28. Carmona S, Zahs K, Wu E, Dakin K, Bras J, Guerreiro R. The role of TREM2 in Alzheimer's disease and other neurodegenerative disorders. Lancet Neurol. 2018;17:721-30.

29. Rogaev El, Sherrington R, Rogaeva EA, Levesque G, Ikeda M, Liang Y, et al. Familial Alzheimer's disease in kindreds with missense mutations in a gene on chromosome 1 related to the Alzheimer's disease type 3 gene [Internet]. Nature. 1995. p. 775-8. Available from: https://doi.org/10.1038/376775a0

30. Sherrington R, Rogaev El, Liang $Y$, Rogaeva EA, Levesque G, Ikeda M, et al. Cloning of a gene bearing missense mutations in early-onset familial Alzheimer's disease. Nature. 1995;375:754-60.

31. Li YM, Xu M, Lai MT, Huang Q, Castro JL, DiMuzio-Mower J, et al. Photoactivated gamma-secretase inhibitors directed to the active site covalently label presenilin 1. Nature. 2000;405:689-94.

32. Ryan NS, Rossor MN. Correlating familial Alzheimer's disease gene mutations with clinical phenotype [Internet]. Biomarkers in Medicine. 2010. p. 99-112. Available from: https://doi.org/10.2217/bmm.09.92

33. Ezquerra $M$, Lleó $A$, Castellví $M$, Queralt $R$, Santacruz $P$, Pastor $P$, et al. A novel mutation in the PSEN2 gene (T430M) associated with variable expression in a family with early-onset Alzheimer disease. Arch Neurol. 2003; 60:1149-51.

34. Sherrington R, Froelich S, Sorbi S, Campion D, Chi H, Rogaeva EA, et al. Alzheimer's disease associated with mutations in presenilin 2 is rare and variably penetrant. Hum Mol Genet. 1996;5:985-8.

35. Cruchaga C, Haller G, Chakraverty S, Mayo K, Vallania FLM, Mitra RD, et al. Rare variants in APP, PSEN1 and PSEN2 increase risk for AD in late-onset Alzheimer's disease families. PLoS One. 2012;7:e31039.

36. Guerreiro RJ, Lohmann E, Kinsella E, Brás JM, Luu N, Gurunlian N, et al. Exome sequencing reveals an unexpected genetic cause of disease: NOTCH3 mutation in a Turkish family with Alzheimer's disease [Internet]. Neurobiology of Aging. 2012. p. 1008.e17-1008.e23. Available from: https:// doi.org/10.1016/j.neurobiolaging.2011.10.009

37. Sassi C, Nalls MA, Ridge PG, Gibbs JR, Lupton MK, Troakes C, et al. Mendelian adult-onset leukodystrophy genes in Alzheimer's disease: critical influence of CSF1R and NOTCH3 [Internet]. Neurobiology of Aging. 2018. p. 179.e17-179.e29. Available from: https://doi.org/10.1016/j.neurobiolaging.2 018.01 .015

38. Schmidt $H$, Zeginigg M, Wiltgen M, Freudenberger P, Petrovic K, Cavalieri M, et al. Genetic variants of the NOTCH3 gene in the elderly and magnetic resonance imaging correlates of age-related cerebral small vessel disease [Internet]. Brain. 2011. p. 3384-97. Available from: https://doi.org/10.1093/ brain/awr252

39. Patel D, Mez J, Vardarajan BN, Staley L, Chung J, Zhang X, et al. Association of Rare Coding Mutations With Alzheimer Disease and Other Dementias Among Adults of European Ancestry [Internet]. JAMA Network Open. 2019 p. e191350. Available from: https://doi.org/10.1001/jamanetworkopen.201 9.1350

40. Guerreiro RJ, Lohmann E, Brás JM, Gibbs JR, Rohrer JD, Gurunlian N, et al. Using exome sequencing to reveal mutations in TREM2 presenting as a frontotemporal dementia-like syndrome without bone involvement. JAMA Neurol. 2013;70:78-84.

41. Guerreiro R, Wojtas A, Bras J, Carrasquillo M, Rogaeva E, Majounie E, et al. TREM2 variants in Alzheimer's disease. N Engl J Med. 2013;368:117-27.

42. Jonsson T, Stefansson H, Steinberg S, Jonsdottir I, Jonsson PV, Snaedal J, et al. Variant of TREM2 associated with the risk of Alzheimer's disease. N Engl J Med. 2013;368:107-16.

43. Korvatska O, Leverenz JB, Jayadev S, McMillan P, Kurtz I, Guo X, et al. R47H Variant ofTREM2Associated With Alzheimer Disease in a Large Late-Onset Family [Internet]. JAMA Neurology. 2015. p. 920. Available from: https://doi. org/10.1001/jamaneurol.2015.0979

44. De Roeck A, Van Broeckhoven C, Sleegers K. The role of ABCA7 in Alzheimer's disease: evidence from genomics, transcriptomics and methylomics. Acta Neuropathol. 2019;138:201-20.

45. De Roeck A, Van den Bossche T, van der Zee J, Verheijen J, De Coster W, Van Dongen J, et al. Deleterious ABCA7 mutations and transcript rescue mechanisms in early onset Alzheimer's disease. Acta Neuropathol. 2017;134:475-87.

46. Pottier C, Hannequin D, Coutant S, Rovelet-Lecrux A, Wallon D, Rousseau S, et al. High frequency of potentially pathogenic SORL1 mutations in autosomal dominant early-onset Alzheimer disease. Mol Psychiatry. 2012;17: 875-9.
47. Nicolas G, Charbonnier C, Wallon D, Quenez O, Bellenguez C, Grenier-Boley $B$, et al. SORL1 rare variants: a major risk factor for familial early-onset Alzheimer's disease. Mol Psychiatry. 2016;21:831-6.

48. Verheijen J, Van den Bossche T, van der Zee J, Engelborghs S, Sanchez-Valle $R$, Lladó $A$, et al. A comprehensive study of the genetic impact of rare variants in SORL1 in European early-onset Alzheimer's disease. Acta Neuropathol. 2016;132:213-24.

49. Campion D, Charbonnier C, Nicolas G. SORL1 genetic variants and Alzheimer disease risk: a literature review and meta-analysis of sequencing data. Acta Neuropathol. 2019;138:173-86.

50. Cuccaro ML, Carney RM, Zhang Y, Bohm C, Kunkle BW, Vardarajan BN, et al. SORL1 mutations in early- and late-onset Alzheimer disease. Neurol Genet. 2016;2:e116.

51. Vardarajan BN, Zhang Y, Lee JH, Cheng R, Bohm C, Ghani M, et al. Coding mutations in SORL1 and Alzheimer disease. Ann Neurol. 2015;77:215-27.

52. Thonberg $\mathrm{H}$, Chiang $\mathrm{H}-\mathrm{H}$, Lilius L, Forsell C, Lindström A-K, Johansson C, et al. Identification and description of three families with familial Alzheimer disease that segregate variants in the SORL1 gene. Acta Neuropathol Commun. 2017;5:43.

53. Le Guennec K, Tubeuf H, Hannequin D, Wallon D, Quenez O, Rousseau S, et al. Biallelic Loss of Function of SORL1 in an Early Onset Alzheimer's Disease Patient. J Alzheimers Dis. 2018;62:821-31.

54. Vardarajan BN, Ghani M, Kahn A, Sheikh S, Sato C, Barral S, et al. Rare coding mutations identified by sequencing of $A$ Izheimer disease genome-wide association studies loci [Internet]. Annals of Neurology. 2015. p. 487-98. Available from: https://doi.org/10.1002/ana.24466

55. Tan M-S, Yu J-T, Jiang T, Zhu X-C, Guan H-S, Tan L. Genetic variation in BIN1 gene and Alzheimer's disease risk in Han Chinese individuals. Neurobiol Aging. 1781;2014(35):e1-8.

56. Bettens K, Brouwers N, Engelborghs S, Lambert J-C, Rogaeva E, Vandenberghe $R$, et al. Both common variations and rare non-synonymous substitutions and small insertion/deletions in CLU are associated with increased Alzheimer risk. Mol Neurodegener. 2012;7:3.

57. Naj AC, Leonenko G, Jian X, Grenier-Boley B, Dalmasso MC, Bellenguez C, et al. Genome-wide meta-analysis of late-onset Alzheimer's disease using rare variant imputation in 65,602 subjects identifies novel rare variant locus NCK2: The International Genomics of Alzheimer's Project (IGAP) [Internet]. bioRxiv. medRxiv; 2021. Available from: http://medrxiv.org/lookup/doi/10.11 01/2021.03.14.21253553

58. Schwartzentruber J, Cooper S, Liu JZ, Barrio-Hernandez I, Bello E, Kumasaka $\mathrm{N}$, et al. Author Correction: Genome-wide meta-analysis, fine-mapping and integrative prioritization implicate new Alzheimer's disease risk genes. Nat Genet. 2021:53:585-6.

59. Logue MW, Schu M, Vardarajan BN, Farrell J, Bennett DA, Buxbaum JD, et al. Two rare AKAP9 variants are associated with Alzheimer's disease in African Americans [Internet]. Alzheimer's \& Dementia. 2014. p. 609-18.e11. Available from: https://doi.org/10.1016/j.jalz.2014.06.010

60. Vardarajan BN, Barral S, Jaworski J, Beecham GW, Blue E, Tosto G, et al. Whole genome sequencing of Caribbean Hispanic families with late-onset Alzheimer's disease [Internet]. Annals of Clinical and Translational Neurology. 2018. p. 406-17. Available from: https://doi.org/10.1002/acn3.537

61. Wetzel-Smith MK, Hunkapiller J, Bhangale TR, Srinivasan K, Maloney JA, Atwal JK, et al. A rare mutation in UNC5C predisposes to late-onset Alzheimer's disease and increases neuronal cell death. Nat Med. 2014;20: 1452-7.

62. Jiao B, Liu X, Tang B, Hou L, Zhou L, Zhang F, et al. Investigation of TREM2, PLD3, and UNC5C variants in patients with Alzheimer's disease from mainland China. Neurobiol Aging. 2014;35:2422.e9-2422.e11.

63. Cukier HN, Kunkle BK, Hamilton KL, Rolati S, Kohli MA, Whitehead PL, et al. Exome Sequencing of Extended Families with Alzheimer's Disease Identifies Novel Genes Implicated in Cell Immunity and Neuronal Function. J Alzheimers Dis Parkinsonism [Internet]. 2017;7. Available from: https://doi. org/10.4172/2161-0460.1000355

64. Dalmasso MC, Brusco LI, Olivar N, Muchnik C, Hanses C, Milz E, et al. Transethnic meta-analysis of rare coding variants in PLCG2, ABI3, and TREM2 supports their general contribution to Alzheimer's disease. Transl Psychiatry. 2019;9:55

65. Conway OJ, Carrasquillo MM, Wang X, Bredenberg JM, Reddy JS, Strickland $\mathrm{SL}$, et al. ABI3 and PLCG2 missense variants as risk factors for neurodegenerative diseases in Caucasians and African Americans. Mol Neurodegener. 2018;13:53. 
66. Bras J, Djaldetti R, Alves AM, Mead S, Darwent L, Lleo A, et al. Exome sequencing in a consanguineous family clinically diagnosed with earlyonset Alzheimer's disease identifies a homozygous CTSF mutation. Neurobiol Aging. 2016;46:236.e1-6.

67. Clarimón J, Djaldetti R, Lleó A, Guerreiro RJ, Molinuevo JL, Paisán-Ruiz C, et al. Whole genome analysis in a consanguineous family with early onset Alzheimer's disease. Neurobiol Aging. 2009;30:1986-91.

68. Prokopenko D, Morgan SL, Mullin K, Hofmann O, Chapman B, Kirchner R, et al. Whole-genome sequencing reveals new Alzheimer's disease-associated rare variants in loci related to synaptic function and neuronal development. Alzheimers Dement [Internet]. 2021; Available from: https://doi.org/10.1 002/alz.12319

69. He L, Loika Y, Park Y, Genotype Tissue Expression (GTEx) consortium, Bennett DA, Kellis M, et al. Exome-wide age-of-onset analysis reveals exonic variants in ERN1 and SPPL2C associated with Alzheimer's disease. Transl Psychiatry. 2021;11:146.

70. Beecham GW, Vardarajan B, Blue E, Bush W, Jaworski J, Barral S, et al. Rare genetic variation implicated in non-Hispanic white families with Alzheimer disease. Neurol Genet. 2018;4:e286.

71. Zhang X, Zhu C, Beecham G, Vardarajan BN, Ma Y, Lancour D, et al. A rare missense variant of CASP7 is associated with familial late-onset Alzheimer's disease. Alzheimers Dement. 2019;15:441-52.

72. Kim M, Suh J, Romano D, Truong MH, Mullin K, Hooli B, et al. Potential lateonset Alzheimer's disease-associated mutations in the ADAM10 gene attenuate a-secretase activity. Hum Mol Genet Oxford Academic. 2009;18: 3987-96.

73. Hartl D, May P, Gu W, Mayhaus M, Pichler S, Spaniol C, et al. A rare loss-offunction variant of ADAM17 is associated with late-onset familial Alzheimer disease. Mol Psychiatry. 2020;25:629-39.

74. Rovelet-Lecrux A, CNR-MAJ collaborators, Charbonnier C, Wallon D, Nicolas $\mathrm{G}$, Seaman MNJ, et al. De novo deleterious genetic variations target a biological network centered on $A \beta$ peptide in early-onset Alzheimer disease. Mol Psychiatry. 2015:1046-56. Available from: http://dx.doi.org/10.1 038/mp.2015.100

75. Helgadottir HT, Lundin P, Wallén Arzt E, Lindström A-K, Graff C, Eriksson M. Somatic mutation that affects transcription factor binding upstream of CD55 in the temporal cortex of a late-onset Alzheimer disease patient. Hum Mol Genet. 2019;28:2675-85.

76. Ghani M, Reitz C, Cheng R, Vardarajan BN, Jun G, Sato C, et al. Association of long runs of homozygosity with Alzheimer disease among African American individuals. JAMA Neurol. 2015;72:1313-23.

77. Cacace R, Heeman B, Van Mossevelde S, De Roeck A, Hoogmartens J, De Rijk P, et al. Loss of DPP6 in neurodegenerative dementia: a genetic player in the dysfunction of neuronal excitability. Acta Neuropathol. 2019;137:90118.

78. Miller JE, Shivakumar MK, Lee Y, Han S, Horgousluoglu E, Risacher SL, et al. Rare variants in the splicing regulatory elements of EXOC $3 L 4$ are associated with brain glucose metabolism in Alzheimer's disease. BMC Med Genomics. 2018;11:76.

79. Bis JC, Jian X, Kunkle BW, Chen Y, Hamilton-Nelson KL, Bush WS, et al. Whole exome sequencing study identifies novel rare and common Alzheimer's-Associated variants involved in immune response and transcriptional regulation. Mol Psychiatry. 2018. Available from: http://dx.doi. org/10.1038/s41380-018-0112-7.

80. Sala Frigerio C, Lau P, Troakes C, Deramecourt V, Gele P, Van Loo P, et al. On the identification of low allele frequency mosaic mutations in the brains of Alzheimer's disease patients. Alzheimers Dement. 2015;11:1265-76.

81. Park JS, Lee J, Jung ES, Kim M-H, Kim IB, Son H, et al. Brain somatic mutations observed in Alzheimer's disease associated with aging and dysregulation of tau phosphorylation. Nat Commun. 2019;10:3090.

82. Tosto G, Vardarajan B, Sariya S, Brickman AM, Andrews H, Manly JJ, et al. Association of variants in PINX1 and TREM2 with late-onset Alzheimer disease. JAMA Neurol. 2019;76:942-8.

83. Kunkle BW, Vardarajan BN, Naj AC, Whitehead PL, Rolati S, Slifer S, et al. Early-onset Alzheimer disease and candidate risk genes involved in endolysosomal transport. JAMA Neurol. 2017;74:1113-22.

84. Zou Y, He W, Wang K, Han H, Xiao T, Chen X, et al. Identification of rare RTN3 variants in Alzheimer's disease in Han Chinese. Hum Genet. 2018;137: 141-50

85. Paracchini L, Beltrame L, Boeri L, Fusco F, Caffarra P, Marchini S, et al. Exome sequencing in an Italian family with Alzheimer's disease points to a role for seizure-related gene 6 (SEZ6) rare variant R615H. Alzheimers Res Ther. 2018; 10:106.

86. Vardarajan BN, Tosto G, Lefort R, Yu L, Bennett DA, De Jager PL, et al. Ultrarare mutations in SRCAP segregate in Caribbean Hispanic families with Alzheimer disease. Neurol Genet. 2017;3:e178.

87. Kohli MA, Cukier HN, Hamilton-Nelson KL, Rolati S, Kunkle BW, Whitehead $\mathrm{PL}$, et al. Segregation of a rare TTC3 variant in an extended family with lateonset Alzheimer disease. Neurol Genet. 2016;2:e41.

88. Pottier C, Ravenscroft TA, Brown PH, Finch NA, Baker M, Parsons M, et al. TYROBP genetic variants in early-onset Alzheimer's disease. Neurobiol Aging. 2016:48:222.e9-222.e15.

89. Hoogmartens J, Hens E, Engelborghs S, Vandenberghe R, De Deyn P-P, Cacace $\mathrm{R}$, et al. Contribution of homozygous and compound heterozygous missense mutations in WWA2 to Alzheimer's disease. Neurobiol Aging. 2021; 99:100.e17-100.e23.

90. Jones L, Holmans PA, Hamshere ML, Harold D, Moskvina V, Ivanov D, et al. Genetic evidence implicates the immune system and cholesterol metabolism in the aetiology of Alzheimer's disease. PLoS One. 2010;5: e13950.

91. Medway CW, Abdul-Hay S, Mims T, Ma L, Bisceglio G, Zou F, et al. ApoE variant p.V236E is associated with markedly reduced risk of Alzheimer's disease. Mol Neurodegener. 2014;9:11.

92. Arboleda-Velasquez JF, Lopera F, O'Hare M, Delgado-Tirado S, Marino C, Chmielewska N, et al. Resistance to autosomal dominant Alzheimer's disease in an APOE3 Christchurch homozygote: a case report. Nat Med. 2019:25:1680-3.

93. Jonsson T, Atwal JK, Steinberg S, Snaedal J, Jonsson PV, Bjornsson S, et al. A mutation in APP protects against Alzheimer's disease and age-related cognitive decline. Nature. 2012;488:96-9.

94. Magno L, Lessard CB, Martins M, Lang V, Cruz P, Asi Y, et al. Alzheimer's disease phospholipase C-gamma-2 (PLCG2) protective variant is a functional hypermorph. Alzheimers Res Ther. 2019;11:16.

95. Takalo M, Wittrahm R, Wefers B, Parhizkar S, Jokivarsi K, Kuulasmaa T, et al. The Alzheimer's disease-associated protective PIcy2-P522R variant promotes immune functions. Mol Neurodegener. 2020;15:52.

96. Andreone BJ, Przybyla L, Llapashtica C, Rana A, Davis SS, van Lengerich B, et al. Alzheimer's-associated PLCY2 is a signaling node required for both TREM2 function and the inflammatory response in human microglia. Nat Neurosci. 2020;23:927-38.

97. Kleineidam L, Chouraki V, Próchnicki T, van der Lee SJ, Madrid-Márquez L, Wagner-Thelen $\mathrm{H}$, et al. PLCG2 protective variant p.P522R modulates tau pathology and disease progression in patients with mild cognitive impairment. Acta Neuropathol. Springer Science and Business Media LLC. 2020;139:1025-44.

98. Sierksma A, Lu A, Mancuso R, Fattorelli N, Thrupp N, Salta E, et al. Novel Alzheimer risk genes determine the microglia response to amyloid- $\beta$ but not to TAU pathology. EMBO Mol Med. 2020. Available from: https://doi. org/10.15252/emmm.201910606.

99. Ghani M, Sato C, Kakhki EG, Gibbs JR, Traynor B, St George-Hyslop P, et al. Mutation analysis of the MS4A and TREM gene clusters in a case-control Alzheimer's disease data set. Neurobiol Aging. 2016;42:217.e7-217.e13.

100. Lupton MK, Proitsi P, Lin K, Hamilton G, Daniilidou M, Tsolaki M, et al. The role of ABCA1 gene sequence variants on risk of Alzheimer's disease. J Alzheimers Dis. 2014;38:897-906.

101. Cruchaga C, Karch CM, Jin SC, Benitez BA, Cai Y, Guerreiro R, et al. Rare coding variants in the phospholipase D3 gene confer risk for Alzheimer's disease. Nature. 2014;505:550-4.

102. Nackenoff AG, Hohman TJ, Neuner SM, Akers CS, Weitzel NC, Shostak A, et al. PLD3 is a neuronal lysosomal phospholipase D associated with $\beta$ amyloid plaques and cognitive function in Alzheimer's disease. PLoS Genet. 2021;17:e1009406

103. Cacace R, Van den Bossche T, Engelborghs S, Geerts N, Laureys A, Dillen L, et al. Rare Variants in PLD3 Do Not Affect Risk for Early-Onset Alzheimer Disease in a European Consortium Cohort. Hum Mutat. Wiley Online Library. 2015;36:1226-35.

104. Hooli BV, Lill CM, Mullin K, Qiao D, Lange C, Bertram L, et al. PLD3 gene variants and Alzheimer's disease. Nature. 2015:E7-8.

105. Lambert J-C, Grenier-Boley B, Bellenquez C, Pasquier F, Campion D, Dartigues J-F, et al. PLD3 and sporadic Alzheimer's disease risk. Nature. 2015:E1.

106. van der Lee SJ, Holstege H, Wong TH, Jakobsdottir J, Bis JC, Chouraki V, et al. PLD3 variants in population studies. Nature. 2015:E2-3. 
107. Heilmann S, Drichel D, Clarimon J, Fernández V, Lacour A, Wagner H, et al. PLD3 in non-familial Alzheimer's disease. Nature. 2015:E3-5.

108. Chilamakuri CSR, Lorenz S, Madoui M-A, Vodák D, Sun J, Hovig E, et al. Performance comparison of four exome capture systems for deep sequencing. BMC Genomics. 2014;15:449.

109. Grozeva D, Saad S, Menzies GE, Sims R. Benefits and Challenges of Rare Genetic Variation in Alzheimer's Disease. Curr Genet Med Rep. 2019;7:53-62.

110. Lee $S$, Abecasis GR, Boehnke M, Lin X. Rare-variant association analysis: study designs and statistical tests. Am J Hum Genet. 2014;95:5-23.

111. Momozawa Y, Mizukami K. Unique roles of rare variants in the genetics of complex diseases in humans. J Hum Genet. 2021;66:11-23.

112. Zuk O, Schaffner SF, Samocha K, Do R, Hechter E, Kathiresan S, et al. Searching for missing heritability: designing rare variant association studies. Proc Natl Acad Sci U S A. 2014;111:E455-64.

113. Holstege H, Hulsman M, Charbonnier C, Grenier-Boley B, Quenez O, Grozeva $D$, et al. Exome sequencing identifies rare damaging variants in the ATP8B4 and $A B C A 1$ genes as novel risk factors for Alzheimer's Disease. bioRxiv. medRxiv. 2020. Available from: http://medrxiv.org/lookup/doi/10.1101/2020. 07.22.20159251.

114. Rentzsch P, Witten D, Cooper GM, Shendure J, Kircher M. CADD: predicting the deleteriousness of variants throughout the human genome. Nucleic Acids Res. 2019:47:D886-94.

115. Quang D, Chen Y, Xie X. DANN: a deep learning approach for annotating the pathogenicity of genetic variants. Bioinformatics. 2015;31:761-3.

116. Mclnnes G, Sharo AG, Koleske ML, Brown JEH, Norstad M, Adhikari AN, et al. Opportunities and challenges for the computational interpretation of rare variation in clinically important genes. Am J Hum Genet. 2021;108:535-48.

117. Eilbeck K, Quinlan A, Yandell M. Settling the score: variant prioritization and Mendelian disease. Nat Rev Genet. 2017;18:599-612.

118. Wright CF, West B, Tuke M, Jones SE, Patel K, Laver TW, et al. Assessing the Pathogenicity, Penetrance, and Expressivity of Putative Disease-Causing Variants in a Population Setting. Am J Hum Genet. 2019;104:275-86.

119. Richards S, on behalf of the ACMG Laboratory Quality Assurance Committee, Aziz N, Bale S, Bick D, Das S, et al. Standards and guidelines for the interpretation of sequence variants: a joint consensus recommendation of the American College of Medical Genetics and Genomics and the Association for Molecular Pathology. Genet Med. 2015:405-23. Available from: https://doi.org/10.1038/gim.2015.30.

120. Lichou F, Trynka G. Functional studies of GWAS variants are gaining momentum. Nat Commun. 2020;11:6283.

121. Novikova G, Andrews SJ, Renton AE, Marcora E. Beyond association: successes and challenges in linking non-coding genetic variation to functional consequences that modulate Alzheimer's disease risk. Mo Neurodegener. 2021;16:27.

122. ENCODE Project Consortium. An integrated encyclopedia of DNA elements in the human genome. Nature. 2012;489:57-74.

123. Cooper-Knock J, Zhang S, Kenna KP, Moll T, Franklin JP, Allen S, et al. Rare Variant Burden Analysis within Enhancers Identifies CAV1 as an ALS Risk Gene. Cell Rep. 2020;33:108456.

124. Wessel J, Majarian TD, Highland HM, Raghavan S, Szeto MD, Hasbani NR, et al. Rare non-coding variation identified by large scale whole genome sequencing reveals unexplained heritability of type 2 diabetes. bioRxiv. medRxiv. 2020. Available from: http://medrxiv.org/lookup/doi/10.1101/202 0.11.13.20221812.

125. Cochran JN, Geier EG, Bonham LW, Newberry JS, Amaral MD, Thompson ML, et al. Non-coding and Loss-of-Function Coding Variants in TET2 are Associated with Multiple Neurodegenerative Diseases. Am J Hum Genet. 2020;106:632-45.

126. Holstege $\mathrm{H}$, Hulsman $\mathrm{M}$, van der Lee $\mathrm{SJ}$, van den Akker EB. The role of agerelated clonal hematopoiesis in genetic sequencing studies. Am J Hum Genet. 2020:575-6.

127. Nelson MR, Tipney H, Painter JL, Shen J, Nicoletti P, Shen Y, et al. The support of human genetic evidence for approved drug indications. Nat Genet. 2015:47:856-60.

\section{Publisher's Note}

Springer Nature remains neutral with regard to jurisdictional claims in published maps and institutional affiliations.

Ready to submit your research? Choose BMC and benefit from:

- fast, convenient online submission

- thorough peer review by experienced researchers in your field

- rapid publication on acceptance

- support for research data, including large and complex data types

- gold Open Access which fosters wider collaboration and increased citations

- maximum visibility for your research: over $100 \mathrm{M}$ website views per year

At BMC, research is always in progress.

Learn more biomedcentral.com/submissions 